\title{
Gallbladder Tubular Carcinoid
}

National Cancer Institute

\section{Source}

National Cancer Institute. Gallbladder Tubular Carcinoid. NCI Thesaurus. Code C96930.

A neuroendocrine tumor that arises from the gallbladder. It does not show the

morphologic characteristics of typical carcinoid tumors (neoplastic cells forming solid nests). In contrast, the tumor cells form small discrete tubules. 